\title{
“NOVO ENSINO MÉDIO. QUEM CONHECE APROVA!": DERIVAS DE SENTIDOS EM UM DISCURSO DE (DES) APROVAÇÃO
}

\author{
"NEW HIGH SCHOOL. THOSE WHO KNOW IT \\ APPROVE!": SENSES DRIFT IN A (DIS)APPROVED \\ SPEECH
}

\author{
Simone Natividade Santos* \\ Fernanda Valeria do Nascimento Borba ${ }^{* * *}$ \\ Josenilda Rodrigues de Lima**** \\ Deyvid Braga Ferreira*****
}

Resumo: A conflituosa mudança de governo no ano de 2016 no Brasil culminou no desmonte de diversas políticas públicas educacionais, a exemplo da reforma do ensino médio. Para estabilizar os sentidos do discurso de aprovação dessa reforma, o governo divulgou diversas propagandas. Objetivamos analisar o funcionamento do discurso presente nessas propagandas e discorrer sobre a dualidade educacional no Brasil, procurando compreender as derivas de sentidos de aprovação. Faz-se um estudo bibliográfico com interlocução com autores que pesquisam sobre políticas educacionais como Frigotto (2001), Gramsci (2004), Kuenzer (2007), Neves (2008). A Análise do Discurso de vertente pecheutiana foi base para análise dos efeitos discursivos. Essa reforma contribui para formar subjetividades flexíveis no contexto do capitalismo em crise e aprofunda as desigualdades sociais.

Palavras-chave: Ensino médio. Análise do discurso. Elitização do ensino.

Aвstract: The conflicting change of government in 2016 in Brazil culminated in the dismantling of several public educational policies, such as the reform of high school. To

\footnotetext{
"Doutoranda em Linguística e Literatura (PPGLL/UFAL); Mestra em Educação (PPGE/UFAL/2014); Especialista em Educação em Direitos Humanos (UFAL/2012); Graduada em Letras (FALE/UFAL/2006). Integra o Grupo de Estudos Discurso e Ontologia (GEDON/PPGLL/UFAL). E-mail: simone.doutorado.sp@gmail.com.

"*" Mestra em Educação (PPGE/UFAL/2016); Graduada em Pedagogia (CEDU/UFAL/2013). E-mail: fvnborba@gmail.com.

"*t" Doutoranda em Linguística e Literatura (PPGLL/UFAL); Mestra em Educação (PPGE/UFAL/2019); Especialista em Gênero e Diversidade na Escola (UFAL/2016); Graduada em Serviço Social (UFAL/2013). Integra o Grupo de Estudos Discurso e Ontologia (GEDON/PPGLL/UFAL). E-mail: josylimazo@hotmail.com.

tantum Doutorando em Linguística e Literatura (PPGLL/UFAL); Mestre em Educação (PPGE/UFAL/2012); Graduado em Direito (CESMAC-AL/2005). Integra o Grupo de Pesquisas em Estado e Políticas Educacionais (GEPE/PPGE/UFAL). E-mail: deyvidbrafe@bol.com.br.
} 
stabilize the senses of the speech of approval of this reform, the government published several advertisements. We aim to analyze the functioning of the discourse present in these advertisements and discuss the educational duality in Brazil, seeking to understand the drift of the meanings of approval. A bibliographic study is carried out with interlocution with authors who research on educational policies such as Frigotto (2001), Gramsci (2004), Kuenzer (2007), Neves (2008). The Analysis of the Discourse of the Pecheutian aspect was the basis for the analysis of the discursive effects. This reform helps to form flexible subjectivities in the context of capitalism in crisis and deepens social inequalities.

KEYwords: High school. Discourse analysis. Elitization of teaching.

\section{INTRODUÇão}

O fim da segunda década do século XXI deixou como marca uma transição conflituosa no panorama político brasileiro. Como reflexo desse conflito, no ano de 2016, assistiu-se ao retrocesso de diversas políticas públicas no governo provisório de Michel Temer, cujas ações colocaram em xeque direitos conquistados desde o início da abertura democrática no país. No cenário educacional, o Brasil retroagiu com imposições impraticáveis aos docentes, enquanto os alunos foram atacados no conteúdo curricular. Estas medidas corroboram com o funcionamento do Estado, que se utiliza de estratégias para manter a massa popular no mesmo patamar social, primando por sujeitos ordeiros e conformados, enquanto que nos bastidores da história se agrava e se aprofundam as desigualdades educacionais com um fim predeterminado - a conservação do status quo.

Este artigo discorre sobre uma das reformas educacionais da gestão de Michel Temer: a reforma do ensino médio, promulgada inicialmente através da Medida Provisória (MP) ${ }^{\circ}$ 746 de 22 de setembro de 2016, convertida na lei ${ }^{\circ}$ 13.415/2017. É uma reforma que parafraseia discursos anteriores sobre a educação de nível médio no Brasil e retoma a historicidade recorrente de reformas educacionais. Dentre essa historicidade tem-se a Reforma João Luiz Alves, em 1925, a Reforma Francisco Campos, em 1932, a Reforma Gustavo Capanema, em 1942, a lei $n^{\circ} 4.024 / 61$, a lei ${ }^{\circ} 5.692 / 1971$, a lei $n^{\circ} 9.394 / 1996$, entre outras. Discursos contidos nessas reformas educacionais são ressignificados na reforma de 2016, divulgada, através de diversas propagandas governamentais, como "Novo Ensino Médio". Em uma destas propagandas é simulado um auditório lotado de jovens que se levantam para se posicionar, aprovando as novas mudanças. As propagandas divulgam a ideia da liberdade de escolha, que permitirá ao aluno cursar o itinerário formativo que quiser, seja propedêutico ou profissionalizante. 
Diante deste apelo midiático, questiona-se: Quem são os alvos dessa proposta? A escolha pelas opções oferecidas neste novo (velho) projeto é realmente uma escolha, ou uma forma de reposicionar sujeitos dentro de um terreno dual e hierárquico? Quais os efeitos de sentidos deste discurso de aprovação da reforma? Desta forma, este artigo visa analisar como funciona o discurso publicitário veiculado pelo Governo Federal e revisitar alguns documentos oficiais que discorrem sobre a dualidade educacional no Brasil, principalmente em relação à etapa do ensino médio, procurando compreender as derivas de sentidos de (des)aprovação presentes nesses discursos.

No que concerne à identidade teórica deste trabalho, será feita uma interlocução com: Frigotto (2001), Gramsci (2004), Kuenzer (2007), Neves (2008), Oliveira (2003), entre outros autores que discutem sobre educação. Para a análise dos efeitos discursivos presentes nas propagandas governamentais, utilizou-se das teorias da Análise do Discurso de vertente francesa pecheutiana. Metodologicamente, foi realizado um levantamento bibliográfico acerca do ensino médio-profissionalizante no Brasil, com destaque para algumas leis e decretos que regulam o ensino médio propedêutico e profissionalizante, tendo o cuidado de trazer os aspectos mais pontuais que engendram esta modalidade de ensino. Em seguida, houve a investigação sobre a proposta governamental presente no documento oficial que rege esta atual reforma e também na campanha publicitária veiculada nos meios de comunicação. Compreende-se que o discurso presente na propaganda governamental funciona por derivas de sentidos, que corrobora para silenciar o movimento de desaprovação, emergido naquele contexto. Ademais, a política educacional em questão contribui para formar subjetividades flexíveis no contexto do capitalismo em crise e aprofunda as desigualdades sociais.

\section{Políticas EdUCACIONAIS E ALGUMAS CONSIDERAÇõES SOBRE ENSINO MÉdIO PROPEDÊUTICO E PROFISSIONALIZANTE}

A Análise do Discurso (AD), de vertente pecheutiana, possibilita pensar um objeto discursivo na relação entre língua, história e ideologia, com os efeitos de sentidos, memória discursiva e interdiscurso que o compõe. Com base nessa perspectiva, não é possível tomar um objeto discursivo sem considerar sua historicidade, que permite sua compreensão para além dos aspectos históricos. Segundo Orlandi (2007a, p. 57), "[...] a historicidade é função da necessidade do sentido no universo simbólico". Assim, trataremos um pouco da historicidade do ensino médio no Brasil, ou seja, como a memória discursiva e sentidos sobre essa etapa da educação foram sendo construídos ao longo da história, refletindo os jogos de forças que perpassam a educação brasileira, possibilitando o acontecimento histórico do "Novo Ensino Médio" e seu discurso de "(des)aprovação" materializado nas propagandas.

A oferta do ensino médio no Brasil compõe as políticas públicas desenvolvidas pelo Estado, as quais surgiram no Brasil e no mundo, não como benesse do Estado, mas como 
estratégia de apaziguamento das expressões da questão social, que envolvem os conflitos entre interesses de classes diferentes (DIÓGENES, 2012). Assim como as demais políticas públicas, as políticas públicas educacionais, fundamentadas pela divisão social do trabalho, expressam seu dualismo no ensino médio, o qual se institucionaliza de maneira seletiva, predeterminando espaços sociais na sociedade capitalista. O ensino médio, portanto, é caracterizado pela dualidade estrutural que caracteriza as políticas públicas, predominando, em um mesmo sistema, duas redes distintas de ensino: propedêutica e profissionalizante. As "mudanças" na política do ensino médio não superam as contradições sociais, econômicas e educacionais existentes. Ao contrário, se organizam em torno da manutenção das relações contraditórias entre capital e trabalho.

Uma dessas políticas dualistas no nível médio foi institucionalizada através da lei $n^{\circ}$ 5.692/1971, a $2^{\text {a }}$ Lei de Diretrizes e Bases (LDB), publicada no governo ditatorial de Médici e embalado pelo discurso do milagre econômico, que resultou na expansão da industrialização e desencadeou a necessidade de mão de obra qualificada. Com a promulgação dessa lei, foi eliminada a necessidade de exames de admissão para ingresso no ensino médio; aumentou-se de 4 para 8 anos a oferta de educação obrigatória ao unir, sob a nomenclatura de "Ensino de $1^{\circ} \mathrm{Grau}$ ", o anterior curso primário e o ciclo ginasial (esse último compunha a "Educação de Grau Médio" anteriormente); e instituiu-se o " $2^{\circ} \mathrm{Grau}$ ”, com duração de três anos e habilitação profissionalizante compulsória. Sua meta era fortalecer a formação profissionalizante, com um currículo reducionista, e conter a demanda de pessoas por acesso ao ensino superior. Sobre isso, Cunha (2017, p. 374) reforça:

[...] os planejadores da ditadura pretendiam desviar para o mercado de trabalho, supostamente carente de técnicos de nível médio, parte dos jovens que aumentavam ano após ano o número de demandantes de vagas nas universidades públicas, cujos "excedentes" engrossavam as manifestações de descontentes.

O último governo militar, na figura de João Figueiredo, rompeu com esse projeto ao sancionar a lei $n^{\circ} 7.044 / 82$, que eliminou a obrigatoriedade de profissionalização. Assim, a "qualificação" do trabalho deu lugar à "preparação para o trabalho". Atualmente, as políticas educacionais no Brasil têm como base a lei nº 9.394/1996 (LDB/1996), a qual normatizou a educação profissional como uma formação adequada para a classe trabalhadora e desvinculada da oferta obrigatória nas escolas de ensino médio. O Projeto de Lei (PL) para promulgação da LDB/1996 foi protocolado ainda no ano de 1988, logo após a abertura democrática no país. Naquele mesmo ano foi apresentado o primeiro substitutivo Jorge Hage, que incorporou contribuições de 13 projetos parlamentares e discussões realizadas em audiências públicas com diversas organizações e instituições da sociedade civil. Segundo Cavalcante (2007, p. 25), 
o referido projeto continha propostas de reorganização do sistema nacional de ensino que vinham ao encontro dos anseios das classes trabalhadoras. A exemplo do movimento dos pioneiros da educação nova de 1930 e dos movimentos em defesa da escola pública (no início da década de 60), a bandeira da escola única, pública, de qualidade, laica unitária e com gestão democrática novamente é empunhada pelos movimentos sociais organizados, principalmente os movimentos estudantil e docente.

Contudo, não prevaleceu a proposta de Jorge Hage. Aprovou-se a proposta elaborada por Darcy Ribeiro, com seu caráter conservador e reacionário e mais alinhado às perspectivas neoliberais. Esse projeto substitutivo propôs que a educação profissional também fosse ofertada fora do sistema de ensino regular "em instituições especializadas ou no âmbito do trabalho, sem vinculação obrigatória com o sistema regular ou supletivo" (NEVES, 2008, p. 197). Colocada como modalidade, a educação profissional se configurou de forma independente da educação regular, o que reforçou ainda mais o caráter dual da educação no Brasil, bem como uma terminalidade educacional precoce para um grande quantitativo de estudantes trabalhadores. Dessa forma, conforme observa Frigotto (2001, p. 83), a LDB/1996 consolidou dois sistemas educativos "um regular - fundamental e médio (educação básica) e superior - e outro sistema (não regular, por dedução) que é da educação profissional dividida em 'básico, técnico e tecnológico".

Corroborando com esse contexto de divisão entre ensino médio e ensino profissional, foi aprovado o decreto $n^{\circ} 2.208 / 1997$, que regulamentou e normatizou a denominada educação profissional, dividindo-a em três níveis: ensino básico, técnico e tecnológico, com a separação formal entre o ensino médio e o técnico. Com o pretexto de atrair para as escolas técnicas as classes populares, efetivou-se a desvinculação entre a educação profissional e a educação propedêutica, estabelecendo duas formas de educação profissional: concomitante ao ensino médio ou subsequente. Esse decreto se configurava em uma investida contra a Rede Federal de Educação Profissional, Científica e Tecnológica, desmontando a educação básica na rede federal de ensino, que seria extinta e substituída pela educação profissionalizante, quando deveria ser promovido o acesso a um número maior de estudantes. Diante de uma resistência da Rede Federal, o processo foi recuado, com lutas pela revogação desse decreto.

Com a publicação do decreto $n^{\circ}$ 5.154/2004, a educação profissional passou a ser articulada ao ensino médio, materializando-se nas formas integrada, concomitante e subsequente. Esse decreto, longe de eliminar o histórico dualismo educacional presente no ensino médio, de certa forma, restabelece a regulamentação da lei $n^{\circ}$ 7.044/1982, que flexibilizou o ensino médio compulsório determinado na lei n ${ }^{\circ}$ 5.692/1971. Em 2008, a alteração de alguns dispositivos da lei $n^{\circ} 9.394 / 1996$, pela lei $n^{\circ} 11.741 / 2008$, estabeleceu a integração da educação profissional e tecnológica com a educação de jovens e adultos e o ensino regular de nível médio, 
através dos cursos de educação profissional técnica de nível médio e educação profissional e tecnológica. Apesar dos avanços em relação ao decreto $n^{\circ} 2.208 / 1997$, o decreto $n^{\circ} 5.154 / 2004$ não foi capaz de romper com a dualidade da educação no nível médio, cujo desenvolvimento no Brasil expressa as determinações da relação entre capital e trabalho. Sobre isso, Kuenzer (2000, p. 13) elucida que

[...] a história do Ensino Médio no Brasil revela as dificuldades típicas de um nível de ensino que, por ser intermediário, precisa dar respostas à ambigüidade gerada pela necessidade de ser ao mesmo tempo, terminal e propedêutico. Embora tendo na dualidade estrutural a sua categoria fundante, as diversas concepções que vão se sucedendo ao longo do tempo, refletem a correlação de funções dominantes em cada época, a partir da etapa de desenvolvimento das forças produtivas.

São leis e decretos que constituem uma historicidade da educação brasileira, marcada pela dualidade estrutural. Não se trata apenas de mudanças nas leis. Elas estão embaladas por discursos que dizem respeito ao contexto socioeconômico, às mudanças nas relações trabalhistas e reforçam a desigualdade social e econômica, corroborando para a exploração dos trabalhadores. O ensino, nos moldes atuais, distancia-se da perspectiva politécnica de ensino e mais se aproxima de uma noção reducionista e utilitária, que "[...] reduz o trabalho à produção material da subsistência e a educação a uma função social seletora e especializante daquela produção" (ARRUDA, 1989, p. 71). Cada vez mais, o ensino médio, especialmente o profissionalizante, vem formando o trabalhador para uma atividade de subsistência, ou seja, o trabalho informal, em que a questão do desemprego é justificada "pela falta de preparação dos mesmos para acompanhar as mudanças existentes no mundo do trabalho" (OLIVEIRA, 2003, p. 36). A atual reforma do ensino médio reitera este dualismo, sob o pretexto da liberdade de escolha, conforme verifica-se na próxima sessão.

\section{LIBERDADE DE ESCOLHA OU LEGITIMAÇÃO DA SEGREGAÇÃO?}

A reforma do ensino médio foi promulgada através da $M P n^{\circ} 746 / 2016$, um instrumento normativo de decisão unilateral, e estabeleceu um currículo por itinerários formativos. Ao invés de disciplinas, o aluno cursará um itinerário a ser escolhido entre os cinco ofertados, conforme nova redação do art. $36^{1}$ da lei n 9.394/1996: I - linguagens e suas tecnologias; II - matemática e suas tecnologias; III - ciências da natureza e suas tecnologias; IV - ciências humanas e sociais aplicadas; V - formação técnica e profissional. Serão obrigatórias apenas as disciplinas língua portuguesa, matemática e língua inglesa. Observa-se que os cincos primeiros itinerários referem-se às áreas de conhecimentos que dão base ao ensino propedêutico. Já o itinerário $\mathrm{V}$ refere-se à formação profissionalizante, esvaziada dos conhecimentos científicos. Ressalte-se

${ }^{1}$ Nova redação dada pela lei 13.415/2017, que alterou definitivamente a estrutura curricular do ensino médio. 
que a própria lei diz, neste art. 36, que esses itinerários serão organizados de acordo com critérios e possibilidades de cada sistema de ensino.

Essa reforma cria uma "polarização das competências" (KUENZER, 2007). Logo, os itinerários formativos da nova versão do ensino médio preparam o jovem para competências distintas, priorizando algumas disciplinas em detrimento de outras. O caminho que leva ao ensino técnico profissionalizante, ligado a um dos pilares da Educação para o Século XXI, denominado de "Aprender a fazer", será direcionado para uma grande parcela da população que depende da venda da força de trabalho, resultando assim na informalidade e/ou subemprego. Enquanto a outra parcela privilegiada/elitizada terá acesso ao ensino propedêutico, culminando na entrada desses nas universidades. Como pontua Orso (2017, p. 52), o "Ensino Superior voltou a ser uma exclusividade da classe dominante. Aos trabalhadores, os cursos técnicos, a 'preparação' ou adestramento para o trabalho". Esse movimento é intrínseco às sociedades de classes, principalmente no sistema capitalista que faz uso de estratégias para conservar a sua lógica, fortalecendo o sistema dualista de educação. A respeito da escola dualista, Gramsci (2004, p. 33) explica: "[...] a escola profissional destinava-se às classes instrumentais, enquanto a clássica destinava-se às classes dominantes e aos intelectuais".

Conforme explica Campos apud Nascimento (2007, p. 78), as políticas educacionais no âmbito do ensino médio têm anunciado o dualismo educacional "[...] fundamentado na divisão social do trabalho, que distribui os homens pelas funções intelectuais e manuais, segundo sua origem de classe, em escolas de currículos e conteúdos diferentes". As alterações no ensino médio se apresentam com uma "nova" roupagem, mas, ao invés de avanços, tem-se um retalho cheio de remendos e costuras, que mais reforçam as políticas anteriores e não trazem mudanças positivas para a formação dos trabalhadores. Por certo, uma educação dual e desigual não representa condição de igualdade para quem não tem condições de vida igualitária. Prevalece é a lógica da diferenciação educacional, com aspectos nada democráticos, principalmente quando determina o tipo de educação que será ofertada a cada classe social: educação profissionalizante para classe trabalhadora e educação propedêutica para classe burguesa. Um discurso, cujos efeitos materiais, dificultam o acesso da classe trabalhadora a outros níveis de ensino e limita cada vez mais sua formação educacional, promovendo segregação.

Com as mudanças, passa-se uma ideia de autonomia do estudante, que fará escolhas de acordo com o seu projeto de vida. Paradoxalmente este "projeto de vida" se refere ao projeto de sociedade a qual estamos inseridos, em que o reposicionamento/direcionamento de sujeitos corroborará com os interesses da classe dominante. Com o intuito de estabelecer sentidos de liberdade de escolha e de aprovação social da nova proposta, foram lançadas, pelo governo federal, peças publicitárias sobre a reforma do ensino médio no ano de 2016, a qual marca mais um acontecimento na historicidade desta etapa de ensino. Realizaremos, na próxima seção, um gesto de análise de duas destas propagandas para compreender seu funcionamento discursivo. 


\section{A (DES)APROVAÇÃo NO SLOGAN “NOVO ENSINO MÉDIO. QUEM CONHECE APROVA”}

Na teoria da Análise do Discurso, de vertente pecheutiana, tem-se a noção de Condições de Produção do Discurso (CPD), que possibilita pensar a relação entre língua, contexto e produção de sentidos de um determinado discurso, pois dizem respeito aos aspectos históricos, linguísticos e psicossociológicos que envolvem o processo de construção e materialização de um discurso. Essa categoria foi cunhada por Pêcheux (2014a), na obra Análise Automática do Discurso (AAD69), quando da inauguração da $\mathrm{AD}$, para mostrar que a exterioridade linguística é determinante na produção do discurso, pois os interlocutores falam de acordo com a situação da enunciação e dos lugares a partir dos quais eles se pronunciam, marcados pelos processos ideológicos.

Orlandi (2015, p. 28) explica que as Condições de Produção "compreendem fundamentalmente os sujeitos e a situação. Também a memória faz parte da produção do discurso". Didaticamente, esta autora considera que as CPD possuem sentido estrito, que se refere ao contexto mais imediato da situação enunciativa, e sentido amplo, que inclui o contexto sócio-histórico e ideológico. O sujeito, portanto, faz uso da linguagem a partir de determinadas condições sócio-históricas, as quais refletem os embates das lutas de classes, as relações de poder e os processos ideológicos.

Pensando as CPD em sentido estrito, o discurso materializado nas propagandas sobre a reforma do ensino médio foi produzido em um contexto de protestos da comunidade educacional e de movimentos sociais contrários à proposta do Governo (REDE BRASIL ATUAL, 2016). Esses movimentos ficaram conhecidos na época como "Movimento Ocupa Escola", por causa das ocupações mobilizadas por estudantes de escolas secundaristas e universidades (GUIA DO ESTUDANTE, 2016). A figura 1 registra a ocupação de um colégio em Brasília. Essas ocupações tomaram conta de todo o Brasil no mês de outubro de 2016, logo após a aprovação da $\mathrm{MP} \mathrm{n}^{\circ}$ 746/2016, em 22 de setembro daquele ano.

Figura 1 - Ocupação de escolas em Brasília

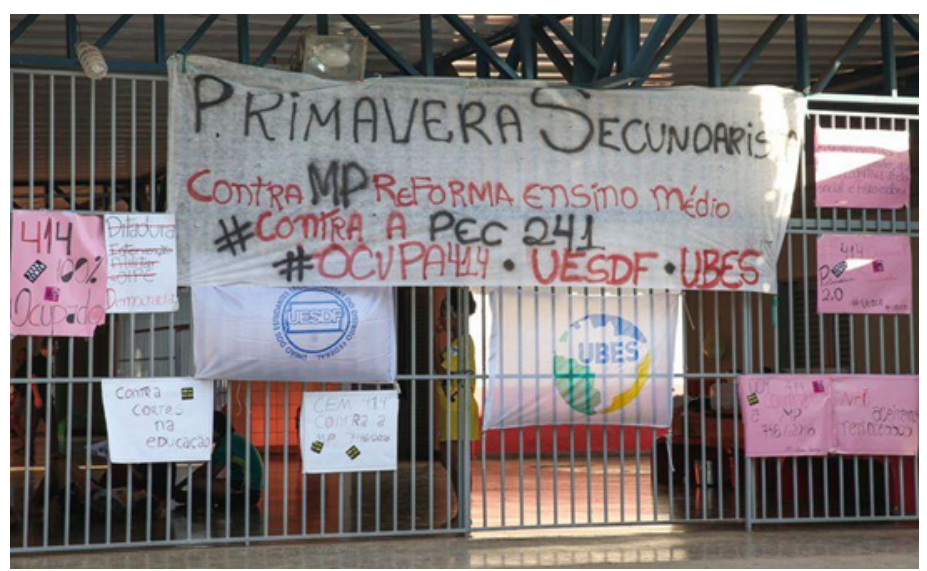

Fonte: Wilson Dias/Agência Brasil apud Guia do estudante, 2016. 
Contrapondo-se a esse movimento, o governo federal publicou várias propagandas, em redes televisivas, no final de 2016. Duas delas, tomadas como objeto de análise aqui, procuraram construir efeitos de sentidos de aprovação. Cada vídeo possui duração de trinta segundos e simula um auditório com jovens na faixa etária correspondente a dos alunos desse nível de ensino, portando itens escolares como bolsas e livros, sentados, com olhar fixo a sua frente como se estivessem a observar uma apresentação em um palco. Não é mostrado palestrante ou palco. Enquanto esta cena é apresentada para o telespectador, o narrador rompe o silêncio dizendo: "Novo Ensino Médio. Quem conhece aprova”. Após esta fala, em um cenário escuro, jovens são destacados sob holofote, à medida que se levantam para expressar seu posicionamento. Posteriormente, tem-se a voz do narrador, cujo desfecho leva aos termos: "liberdade de escolha", "liberdade de decidir o seu futuro", "vocação", "querer" e "aprovar". Enquanto o narrador fala, os jovens são apresentados com semblantes felizes, entusiasmados e contemplativos, como se vislumbrassem o futuro após a reforma. Para finalizar os vídeos, um/a personagem aluno/a, olhando para a câmera, e não mais para o palco imaginário, aponta para o telespectador, pisca um olho e fala: “Quem conhece o Novo Ensino Médio, aprova!”. Durante esta última fala, é projetado na imagem o seguinte texto em destaque e letras em caixa alta: "Já é assim com 72\% dos brasileiros. Fonte: Pesquisa Ibope nov./2016." Os vídeos estão disponíveis no canal do Ministério da Educação na plataforma de compartilhamento de vídeos Youtube (BRASIL, 2016a; BRASIL, 2016b). A Figura 2 reproduz um recorte de um destes vídeos, seguido da transcrição dos enunciados emitidos pelos/as personagens.

Figura 2 - Vídeo 1 da Propaganda "Novo Ensino Médio: quem conhece aprova”

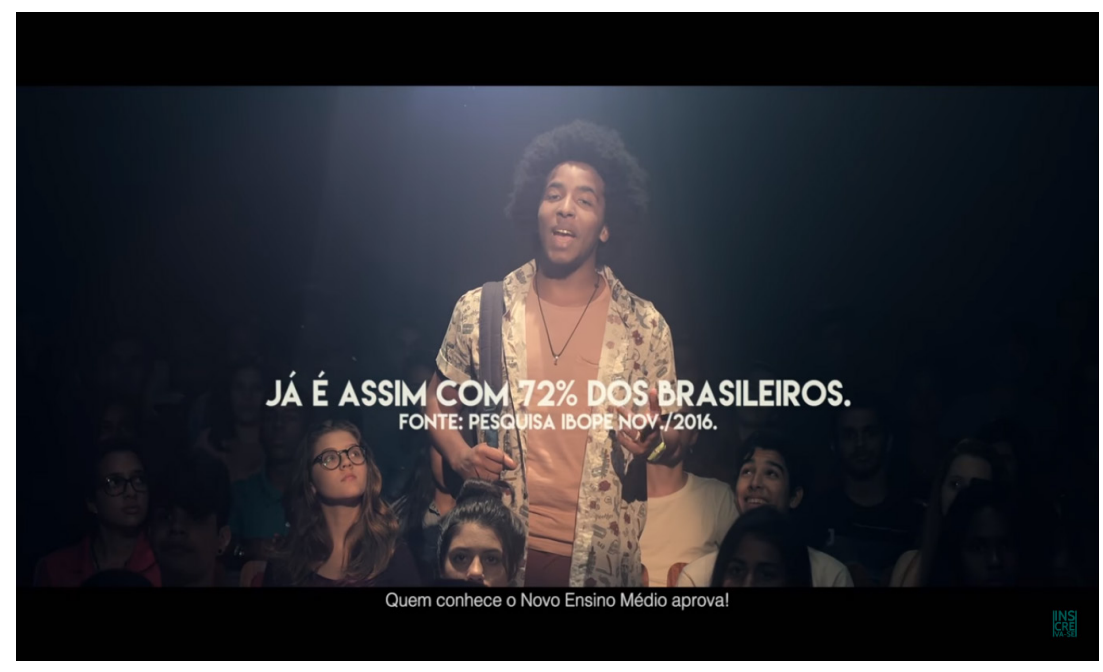

Fonte: BRASIL, 2016a.

Narrador: Novo Ensino Médio. Quem conhece aprova.

Aluna 1: Eu escolho o que eu vou estudar? Então é claro que eu aprovo 
Aluno 1: Minha vocação, sim, eu aprovo.

Aluna 2: Eu quero.

Aluno 2: Eu aprovo.

Narrador: Com o Novo Ensino Médio, você tem mais liberdade para escolher o que estudar, de acordo com a sua vocação. É a liberdade que você queria para decidir o seu futuro.

Aluno 3: Quem conhece o novo Ensino Médio aprova!

Narrador: Acesse o site e saiba mais. Ministério da Educação. Governo Federal. Ordem e Progresso. (BRASIL, 2016a, grifo nosso).

Observa-se um revezamento de falas entre diferentes sujeitos no decorrer do vídeo. $\mathrm{O}$ narrador introduz o vídeo e, em seguida, 5 alunos/jovens ( 2 mulheres e 3 homens) da plateia, um de cada vez, se levantam. Tenta mostrar o protagonismo tanto de homens quanto de mulheres, mas especificamente jovens, em decisões de políticas educacionais. Apreende-se, da ideia geral dos enunciados, que o "Novo Ensino Médio" estava sendo apresentado naquele momento para os ali presentes no auditório imaginário, os quais, a partir do momento que conhecessem a proposta, deveriam votar, como se estivessem em uma assembleia, reunião. No entanto, não é sinalizada nenhuma contraproposta ou modificações no projeto, tal como ocorre em sessões de aprovações de propostas sob regime democrático. A proposta, que já chega pronta e elaborada por outros de algum outro lugar, é abraçada unanimemente pelo auditório. Assim, os ali presentes parecem não ter direito à voz para contrapropor-se, mas apenas direito a voto de aprovar ou desaprovar, querer ou não querer. Não há espaço para diálogo e retificações.

Contudo, ainda é possível observar uma deriva de sentido neste ato de aprovar ou desaprovar presente nesta propaganda, pois, apesar de parecer que os jovens têm direito a voto, a proposta já vem com uma indução à aprovação daqueles, já que 72\%, de não se sabe onde, já aprovaram. Assim, aqueles do auditório que estavam agora conhecendo o Novo Ensino Médio, ou o público-alvo que assiste a propaganda, também deveriam aprovar e fazer parte deste grupo que aprova. A porcentagem de estatística de aprovação funciona em um movimento no sentido de convencimento. Ora, se A, B, C, D aprovam, porque você não aprovaria? Fica subentendido que quem reprova não faz parte das estatísticas. Se $72 \%$ aprovou, porque você ficaria de fora? A tática aqui é convencer a coletividade e criar adesão suficiente para validar a proposta governamental. Prontamente, o sujeito que se filia ao posicionamento de reprovação desta proposta tem seu discurso anulado/apagado, pois ele não foi recrutado, adestrado e se torna um empecilho. Nesta direção, dar visibilidade a quem reprova não coopera com os interesses estatais. Em contrapartida, quem aprova é reverenciado como aquele que está inserido na coletividade e representa os $72 \%$, estatística invisível que serve apenas para maquiar e dar visibilidade ao discurso governamental de que foram ouvidos e aceitaram passivamente a nova proposta, alinhando-se às expectativas do Estado. 
Neste sentido, as palavras "eu aprovo" e "eu quero" podem ser parafraseadas por "eu me submeto", "eu aceito". Ao mesmo tempo em que a linguagem utilizada tenta convencer o telespectador de que há um protagonismo por parte dos alunos do ensino médio no processo de aprovação da proposta, este protagonismo não existe, já que eles estão ali apenas para aceitar/se submeter, sem questionamentos e contrapropostas, às medidas apresentadas pelo Governo. A propaganda reforça exatamente a forma como essa reforma foi promulgada, através de Medida Provisória, ato unilateral, autoritário e sem diálogo com a sociedade. A palavra "aprova" ou "aprovo" é repetida em quase todos os enunciados deste vídeo 1 da propaganda, fazendo um eco que procura aprisionar os sentidos sobre a aceitação dessa reforma diante do contexto de movimentos de resistência no momento em que a propaganda atinente a ela foi veiculada.

Em uma propaganda ou peça publicitária, como qualquer outro gênero discursivo, as estratégias utilizadas buscam alcançar um objetivo, por isso, cada cenário, personagem e falas procuram manter a identificação com o público-alvo, de forma que este se sinta representado. Portanto, trazer jovens na posição de protagonistas na propaganda do Governo já sinaliza um contra discurso em relação aos que, naquelas Condições de Produção, possuíam uma posição-sujeito diferente da do Governo. Logo, ao dizer que "Quem conhece o Novo Ensino Médio, aprova”, o Governo tenta silenciar os posicionamentos de especialistas, professores e alunos contrários à proposta e convencer que a desaprovação de alguns decorre da falta de conhecimento sobre a reforma, aprisionando assim os sentidos.

O silêncio é outra categoria fundamental para pensar o funcionamento de um discurso. Segundo Orlandi (2007b, p. 31), o silêncio é fundador da significação e permite a livre mobilidade dos sujeitos e dos sentidos. Ele significa por si só, por isso "ao invés de pensar o silêncio como falta, podemos, ao contrário, pensar a linguagem como excesso". Além do silêncio como fundador, a autora apresenta outra categorização: o silenciamento ou a política do silêncio. Enquanto o silêncio fundador significa por si mesmo sem estabelecer nenhuma divisão, "a política do silêncio se define pelo fato de que ao dizer algo apagamos necessariamente outros sentidos possíveis, mas indesejáveis, em uma situação discursiva dada” (ORLANDI, 2007b, p. 73). A utilização da linguagem, portanto, "estabiliza o movimento dos sentidos" (ORLANDI, 2007b, p. 27), domesticando a significação. A linguagem funciona para aprisionar o silêncio, pois, na política do silêncio, é preciso dizer algo e estabilizar os sentidos para que o inconveniente não seja dito. Dizer "aprova/aprovo/72\% aprova" silencia o inconveniente dos movimentos de desaprovação que marcou o contexto de promulgação da reforma do ensino médio no ano de 2016.

De acordo com Orlandi (2007b, p. 48), também é possível pensar o silêncio na relação com o sujeito do discurso. Nesta relação, a "opacidade do Outro se manifesta", sinalizando a heterogeneidade que constitui o sujeito. Para a autora, "O outro está presente mas no discurso, de modo ambíguo (presente e ausente)". Sobre essa heterogeneidade constitutiva do sujeito 
e do discurso, Pêcheux (2014a, p. 313) explicou que é o que permite "tematizar [...] as formas linguístico-discursivas do discurso-outro: - discurso de um outro, colocado em cena pelo sujeito, ou discurso do sujeito se colocando em cena como um outro". A identidade do sujeito é marcada por esta heterogeneidade, por isso, tanto o sujeito quanto o discurso são atravessados por um "discurso-outro". Com isso, Pêcheux desconstrói a ideia de um discurso ou sujeito homogêneo, plenamente interpelado. Pêcheux (2014a, p. 313) afirma ainda que "nos pontos de deriva em que o sujeito passa no outro, [...] o controle estratégico de seu discurso lhe escapa".

Esta heterogeneidade e presença do outro no discurso de aprovação do Novo Ensino Médio pode ser observada nos discursos enunciados pela juventude, protagonista na propaganda, que enuncia de uma posição-sujeito de direito, com enunciados do tipo "Eu aprovo"/ "Eu quero". Verifica-se neste "eu" a passagem do "discurso de um outro". O sujeito que enuncia o discurso do "Novo Ensino Médio", no caso, o Ministério da Educação, se coloca em cena, na propaganda, como um outro, como o sujeito a quem se destina este discurso, no caso, os jovens alunos do ensino médio. No "eu” da propaganda ressoa a voz do Ministério da Educação (Representante do Poder Estatal), falando sobre estes jovens. Há a voz do personagem aluno designado como "eu" e há a voz do Governo falando sobre este aluno. Assim, ao falar, estes jovens são falados. Pode-se dizer que o "eu" é atravessado por um "vocês". Nessa simbiose entre o sujeito e "um outro" ocorre a captura da subjetividade, a cooptação e persuasão do público-alvo dessa reforma. Nisso, atravessa a heterogeneidade, as rupturas, as contradições e silenciamentos, compondo o discurso e o sujeito. Esta mesma heterogeneidade e atravessamento do Outro no discurso sobre o Novo Ensino Médio é observada no vídeo 2 deste conjunto de propaganda que procura tratar do processo de aprovação da reforma.

Figura 3 - Vídeo 2 da propaganda "Novo Ensino Médio: quem conhece aprova”

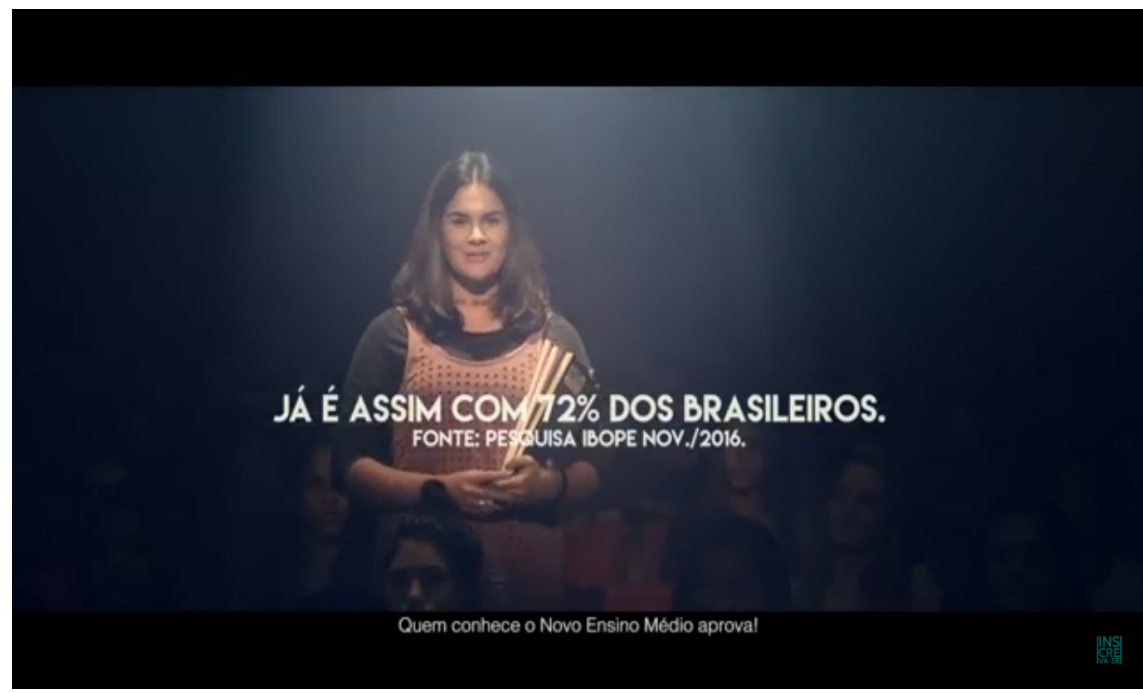

Fonte: BRASIL, 2016b. 
Narrador: Novo Ensino Médio. Quem conhece aprova.

Aluno 1: Eu quero fazer jornalismo.

Aluna 1: Eu quero ser professora. É o que eu amo.

Aluno 2: E eu, designer de games.

Aluna 2: Eu quero um curso técnico para já poder trabalhar.

Narrador: Com o Novo Ensino Médio, você tem mais liberdade para escolher o que estudar, de acordo com a sua vocação. É a liberdade que você queria para decidir o seu futuro.

Aluna 3: Quem conhece o novo Ensino Médio aprova!

Narrador: Acesse o site e saiba mais. Ministério da Educação. Governo Federal. Ordem e Progresso. (BRASIL, 2016b, grifo nosso).

Tal como o primeiro vídeo da peça publicitária, descrito nas páginas anteriores, o vídeo 2 aqui analisado também faz o jogo de revezamento entre sujeitos diferentes em cada enunciado. O narrador introduz o vídeo com a fala "Novo Ensino Médio. Quem conhece aprova!" e, em seguida, cinco jovens de gêneros diferentes (desta vez, 3 mulheres e 2 homens) se levantam no auditório para emitir posicionamentos sobre o que, no contexto encenado, lhes foi apresentado. Contudo, diferentemente da primeira peça publicitária, aqui parece que os sujeitos ali representados foram questionados sobre profissões e formação acadêmica e respondem citando as profissões que querem/devem seguir, como "jornalismo", "professora", "designer de games" e "curso técnico". Aqui a palavra "querer" faz eco no discurso, sendo repetida em todas as falas dos/as personagens de forma explícita ou elipticamente. Nos termos da AD, a terminologia "querer" constitui-se em "pré-construído", conceito definido por Paul Henry para, segundo Pêcheux (2014b, p. 89), "[...] designar o que remete a uma construção anterior, exterior, mas sempre independente, em oposição ao que é 'construído' pelo enunciado". Segundo Cavalcante (2007, p. 49), o pré-construído “[...] designa representações sociais consolidadas", prontas para serem convocadas pelo sujeito que enuncia. Ao convocar estes enunciados, o sujeito pensa ser dono do dizer, fazendo funcionar a evidência dos sentidos, atravessado pelo esquecimento ideológico que constitui todo enunciado. O "querer", nessa propaganda, retomando o pré-construído "querer é poder", "[...] exalta o sujeito livre e poderoso, que é capaz de realizar o que quiser" (MAGALHÃES, 2013, p.31), desde que o queira. Contudo, silencia-se que as decisões do sujeito são tomadas de acordo com as condições materiais de cada realidade e, portanto, as escolhas estão limitadas às possibilidades impostas pela realidade material.

Também é possível observar que, ao trazer as profissões para o contexto de uma reforma educacional, este discurso é atravessado pelos já-ditos, interdiscursos, sobre educação utilitarista, voltada para o mercado de trabalho, desconsiderando-se a formação humana dos sujeitos. Como vimos nas páginas anteriores, este utilitarismo tem sido marcante na memória 
discursiva da educação brasileira e, por causa disto, diversas reformas foram feitas para adequação às exigências do mercado, em cada período histórico.

Sobre as escolhas profissionais citadas pelos/as personagens, evidenciam-se as questões de gênero. Enquanto os personagens do gênero masculino apenas dizem o que querem fazer, as do gênero feminino precisam justificar suas escolhas. A personagem aluna $n^{\circ} 1$ diz: "Eu quero ser professora. É o que eu amo". O discurso presente nesta formulação aciona a memória discursiva sobre a formação e trabalho docente, como uma escolha profissional historicamente ligada ao cuidado feminino, desvalorizada e institucionalmente mal remunerada, necessitando assim de uma justificativa sentimental para tal escolha. Já a personagem aluna n² diz: "Eu quero um curso técnico para já poder trabalhar". O advérbio "já”, neste discurso, funciona para intensificar a necessidade de urgência de inserção no mercado de trabalho, em curto espaço de tempo. O que provocaria essa urgência por "já poder trabalhar"? Quem são estes sujeitos que precisam de um curso técnico para poder, em um curto espaço de tempo, começar a trabalhar? Mais uma vez observa-se um silenciamento sobre as condicionalidades desta "escolha".

Ponce (2001) discute sobre a relação entre história da educação e trabalho e explica que, a partir da divisão social do trabalho e consequente surgimento da sociedade de classes e da propriedade privada, algumas funções sociais passaram a ser mais valorizadas que outras. O trabalho intelectual tornou-se privilégio de alguns que detinham os meios de produção e a riqueza acumulada e o trabalho material destinou-se às classes inferiores que sobreviviam da força de trabalho. As opções que se apresentavam para os que não detinham os meios de produção era morrer de fome ou trabalhar para a classe dominante. Assim, os que precisavam "já" começar a trabalhar seria a classe dominada que precisava vender a sua força de trabalho em troca dos meios de subsistência. Ponce (2001) mostra que estes fatores definiram os rumos da educação. Para os membros das classes afortunadas, havia o direito aos conhecimentos sistematizados, mas para os demais, apenas o conhecimento vulgar, reforçando os privilégios de uma classe sobre a outra.

Esta memória discursiva sobre educação é acionada nas propagandas governamentais. Elas não mencionam sobre as particularidades que levam um jovem a "querer um curso técnico para já poder trabalhar". Esse "querer" é condicionado pelas condições sociais de existência. Este jovem, silenciado na propaganda, é o jovem que compõe a classe trabalhadora e que, nos últimos anos teve direito de acesso ao ensino médio, ao conhecimento sistematizado, tornando-se o maior contingente de estudantes de escolas públicas de nível médio no país.

Funcionando conjuntamente com o discurso presente em "eu quero" está o discurso sobre liberdade enunciado pela fala do narrador no trecho: "Com o Novo Ensino Médio, você tem mais liberdade para escolher o que estudar, de acordo com a sua vocação. É a liberdade que você queria para decidir o seu futuro". Questionamos então: esse jovem está de fato decidindo seu futuro ou o Estado já decidiu por ele? Segundo Amaral (2005), a noção de liberdade 
no modo de produção capitalista está associada à propriedade privada e, para que ela possa ser assegurada, associa-se à noção de igualdade, com base no princípio de que todos são iguais perante a lei. É uma igualdade limitada apenas ao aspecto jurídico. O mercado é o meio pelo qual se constrói o imaginário da liberdade e igualdade que funcionam sustentando "as relações de troca que são o fundamento da sociedade capitalista” (AMARAL, 2005, p. 141). Nestas relações, a mercadoria a ser trocada deverá ser propriedade privada de alguém que seja livre e igual para vender esta mercadoria. No caso dos trabalhadores, a mercadoria é a sua força de trabalho. Assim, ao acionar o discurso da liberdade, o Estado procura quebrar qualquer resistência, simulando a possível oferta daquilo que o jovem quer/necessita. Contudo, sua liberdade limita-se à submissão aos ditames do mercado de trabalho regido pelo capital.

O jogo persuasivo operado com o termo querer é uma impiedosa forma de atrair os jovens da camada mais pobre rumo a um futuro de trabalho precarizado. Já a escolha que leva à universidade é distanciada da camada menos favorecida. A terminologia "querer", neste caso, se traduz em necessidade, o que acaba atraindo o aluno que necessita da venda de sua força de trabalho. O Estado opera pelo caráter de convencimento assentado no discurso do "querer é poder", uma vez que, através da "pseudo" livre escolha, o aluno é levado a aceitar a proposta governamental. Inconscientemente, o jovem é capturado por este discurso do Estado.

Questiona-se então: a quem interessa essa aprovação? Observamos que o sujeito deste discurso da aprovação da reforma é o governo federal, o qual representa o Estado, cuja função é a manutenção da ordem social vigente, de forma que se intensifique a exploração de uma classe sobre a outra. O Estado representa os interesses da classe dominante, a qual detém os meios de produção, a riqueza acumulada e possui o poder para definir os rumos da economia e, portanto, da educação. Com a reforma do ensino médio não seria diferente, por isso ela prevê uma formação flexível para um contexto de trabalho flexível e sem garantias, alinhando-se aos interesses do capitalismo em crise.

\section{UMA GERAÇÃO DE SUBJETIVIDADES FLEXÍVEIS EM FORMAÇÃO}

Além das Condições de Produção do Discurso em sentido estrito, é preciso pensar também nas condições amplas, que dizem respeito a como determinado discurso se constituiu no processo sócio-histórico mais amplo. Courtine (2014, p. 104), explica que “[...] toda formulação apresenta em seu 'domínio associado' outras formulações que ela repete, refuta, transforma, denega..., isto é, em relação às quais ela produz efeitos de memória específicos [...]”. A reforma do ensino médio, aqui analisada, e as características que ela materializa, acionam a memória de outras reformas da educação brasileira e, ao mesmo tempo, reflete o contexto de mudanças econômicas e trabalhistas.

A crise econômica que atravessa o Brasil neste século XXI, demonstra que o Estado é bem pontual no que se refere a proteção do capital. Rapidamente, inúmeras reformas são 
apresentadas com o intuito de reajustar o capitalismo, com a pretensão de mantê-lo estruturalmente no mesmo patamar. Na conjuntura atual, o capitalismo se apropria do conhecimento produzido pela humanidade e evita seu alcance ao maior número de pessoas e, portanto, restringe seu acesso a um seleto grupo. Por outro lado, os que se encontram à margem deste conhecimento tornam-se mão de obra barata, configurando-se apenas como uma das peças desta engrenagem.

Na sociedade hodierna, este processo é realizado na manufatura, ao destruir o trabalhador “[...] reduzindo-o a uma fração de si mesmo, e completa-se na indústria moderna, que faz da ciência uma força produtiva independente de trabalho, recrutando-a para servir ao capital" (MARX; ENGELS, 1992, p. 22). Diante disto, o aluno do ensino médio que "opta" pelo ensino profissionalizante será recrutado para ocupar espaços de trabalhos precarizados no sistema capitalista neoliberal e é neste aspecto que essa reforma possui uma concepção reducionista. Estamos diante da formação flexível que tem como objetivo produzir subjetividades flexíveis, a partir das diferenças na origem de classe, particularmente, os que vivem do trabalho manual. Kuenzer e Grabowsk (2016, p. 27) apresentam elementos do que vem a ser a formação flexível:

[...] adquirem conhecimentos genéricos que lhes permitirão exercer, e aceitar, múltiplas tarefas no mercado flexibilizado. Ser multitarefa, neste caso, implica em exercer trabalhos simplificados, repetitivos, fragmentados, para o que é suficiente um rápido treinamento.

Por isso, as ações da política de educação profissional dirigidas à inclusão social são uma forma de inclusão excludente, como bem colocou Kuenzer (2007). Para a autora, no regime de acumulação flexível, os desempregados e populações em situação de risco social, ou a parcela de trabalhadores desempregados, conhecem dois processos que mantêm uma relação dialética entre si. Como afirma:

[...] do ponto de vista do mercado, ocorre um processo de exclusão da força de trabalho dos postos reestruturados, para incluí-la de forma precarizada em outros pontos da cadeia produtiva. Já do ponto de vista da educação, se estabelece um movimento contrário, dialeticamente integrado ao primeiro: por força de políticas públicas 'professadas' na direção da democratização, aumenta-se a inclusão em todos os pontos da cadeia, mas se precarizam os processos educativos, que resultam em mera oportunidade de certificação, os quais não asseguram nem inclusão nem permanência (KUENZER, 2007, p. 492-493).

De acordo com esta conjuntura, formar subjetividades flexíveis requer a criação de um currículo flexível que atenda às demandas impostas pelo capital. O abismo educacional cela seu compromisso ao prometer um ensino médio atraente do ponto de vista curricular. Sendo que o que impera nas propagandas é a liberdade de escolha sobre qual rumo profissional o 
aluno deve seguir. Portanto, embora esta "liberdade" esteja desarmando e aproximando o aluno da proposta governamental, simultaneamente está, também, aprisionando-o a uma decisão realizada antecipadamente pelo Estado.

\section{Considerações finaIs}

A educação deveria priorizar o pleno desenvolvimento dos sujeitos, seu preparo para o exercício da cidadania e sua qualificação para o trabalho. No entanto, o que se vê são reformas educacionais que não alteram as condições de vida do trabalhador e não proporcionam uma formação integral. O Estado capitalista para obtenção do consenso entre as classes sociais, (re)cria reformas no ensino médio para manutenção da hegemonia da classe do poder e assim promete "resolver" as contradições existentes entre as frações de classe: dominante e dominada, estabelecendo o consenso ativo, principalmente com a promessa de inclusão social, que mais exclui os trabalhadores de seus trabalhos considerados seguros, para inseri-los em formas de trabalho desestruturados.

Com estas medidas, ao avesso do que seria "democracia", pois, apesar das propagandas acerca do Novo Ensino Médio alegar que, através da Pesquisa realizada pelo Instituto Brasileiro de Opinião Pública e Estatística (IBOPE), 72\% da população aprovou esta medida, compreende-se que esta é uma estratégia de legitimação de uma medida autoritária e não traz os números reais, os dados da pesquisa a qual essa porcentagem se refere. O Novo Ensino Médio, conforme menciona Orso (2017, p. 69), "[...] trata-se de uma reforma que patrocina a ignorância e avança rumo ao retrocesso" e reitera a historicidade educacional brasileira que sempre manteve uma educação pública dualista e dilacerada, (de)formada, cujo desfecho recai no sucateamento e desmonte das políticas instituídas.

As escolas públicas não terão suporte para oferecer a escolha mais assertiva. Consequentemente, os estudantes serão obrigados a seguir algo impositivo. A nova reforma constitui-se, em grande parte, em um retrocesso histórico no que se refere à educação geral e profissional do trabalhador brasileiro. As "mudanças" se manifestam mais claramente na execução dos programas, na formação real do trabalhador, que continua aligeirada e superficial.

Essa reforma, não supera a correlação de forças existentes entre capital e trabalho, e sim legitima o sistema capitalista e fornece um equilíbrio de forças, que mais interessa aos anseios do bloco do poder. Diferentemente do discurso que coloca a educação como responsável pela inserção no mundo do trabalho, é preciso compreender que a educação isoladamente não origina emprego nem renda. Nos moldes ofertados por essa reforma, contribui para manutenção desigual da sociedade de classe, legitimando a segregação social.

Em tempos de retrocessos, representados por Medidas Provisórias, Projetos de Lei, Proposta de Emendas Constitucionais e toda uma série de ajustes, concluir este texto é um 
ato de resistência, uma forma de "ousar se revoltar", nos termos que preconiza a Análise do Discurso, contra discursos que corroboram para destituição de direitos e exploração da classe trabalhadora.

\section{REFERÊNCIAS}

AMARAL, M. V. B. Discurso e relações de trabalho. Maceió: Edufal, 2005.

ARRUDA, M. A articulação trabalho-educação visando uma democracia integral. In: GOMES, C. M. (Org.). Trabalho e conhecimento: dilemas na educação do trabalhador. São Paulo: Autores Associados, 1989.

BRASIL. Decreto $\mathbf{n}^{\mathbf{0}} \mathbf{2 . 2 0 8}$, de 17 de abril de 1997. Regulamenta o $\$ 2^{\circ}$ do art. 36 e os arts. 39 a 41 da Lei $n^{\circ}$ 9.394, de 20 de dezembro de 1996, que estabelece as diretrizes e bases da educação nacional, e dá outras providências. Disponível em: http://www.planalto.gov.br/ccivil_03/ decreto/D2208.htm. Acesso em: 19 abr. 2021.

BRASIL. Decreto $\mathbf{n}^{\circ}$ 5.154, de 23 de julho de 2004. Regulamenta o $\$ 2^{\circ}$ do art. 36 e os arts. 39 a 42 da Lei $n^{\circ}$ 9.394, de 20 de dezembro de 1996, que estabelece as diretrizes e bases da educação nacional. Disponível em: http://www.planalto.gov.br/ccivil_03/_ato2004-2006/2004/decreto/ d5154.htm. Acesso em: 19 abr. 2021.

BRASIL. Lei $\mathbf{n}^{\circ}$ 5.692, de 11 de agosto de 1971. Fixa Diretrizes e Bases para o ensino de $1^{\circ}$ e $2^{\circ}$ graus, e dá outras providências. Brasília, DF: Presidência da República 1971. https://www2. camara.leg.br/legin/fed/lei/1970-1979/lei-5692-11-agosto-1971-357752-publicacaooriginal-1-pl. html. Acesso em: 19 abr. 2021.

BRASIL. Lei $\mathbf{n}^{\mathbf{0}} \mathbf{7 . 0 4 4}$, de 18 de outubro de 1982. Altera dispositivos da Lei $\mathrm{n}^{0}$ 5.692, de 11 de agosto de 1971, referentes a profissionalização do ensino de $2^{\circ}$ grau. Disponível em: http:// www.planalto.gov.br/ccivil_03/leis/L7044.htm. Acesso em: 20 jul. 2017.

BRASIL. Lei $\mathbf{n}^{\mathbf{0}}$ 9.394, de 20 de dezembro de 1996. Estabelece as diretrizes e bases da educação nacional. Disponível em: http://portal.mec.gov.br/arquivos/pdf/ldb.pdf. Acesso em: 19 abr. 2021.

BRASIL. Lei $\mathbf{n}^{\mathbf{0}} \mathbf{1 1 . 7 4 1}$, de 16 de julho de 2008. Altera dispositivos da Lei no 9.394, de 20 de dezembro de 1996, que estabelece as diretrizes e bases da educação nacional, para redimensionar, institucionalizar e integrar as ações da educação profissional técnica de nível médio, da educação de jovens e adultos e da educação profissional e tecnológica. Disponível em: www. planalto.gov.br/ccivil_03/_Ato2007.../2008/Lei/L11741.htm. Acesso em: 19 abr. 2021.

BRASIL. Lei $\mathbf{n}^{\circ} \mathbf{1 3 . 4 1 5}$, de 16 de fevereiro de 2017. Altera a Lei de diretrizes e bases da educação nacional. Diário Oficial [da] República Federativa do Brasil, Poder Executivo, Brasília, DF, 17 fev. 2017a. Seção 1, p. 1-3. Disponível em: http://pesquisa.in.gov.br/imprensa/jsp/visualiza/ index.jsp?data=17/02/2017\&jornal=1\&pagina=1\&totalArquivos=440. Acesso em: 6 mar. 2017. 
BRASIL. Ministério da Educação. Com o Novo Ensino Médio, você tem mais liberdade para escolher o que estudar! 26 dez. 2016a. (30s). Disponível em: https://www.youtube.com/ watch?v=kdERkLO3eTs. Acesso em: 13 abr. 2021.

BRASIL. Ministério da Educação. O Novo Ensino Médio vai deixar o aprendizado mais estimulante e compatível com a sua realidade!. 26 dez. 2016b. (30s). Disponível em: https:// www.youtube.com/watch?v=7_FdhibioyQ. Acesso em: 13 abr. 2021.

CAVALCANTE, M. S. A. O. Qualidade e cidadania nas reformas da educação brasileira: o simulacro de um discurso modernizador. Maceió: Edufal, 2007.

COURTINE, J-J. Análise do discurso político: o discurso comunista endereçado aos cristãos. Tradução: Cristina de Campos Velho Birck et al. São Carlos: EdUFSCar, 2014.

CUNHA, L. A. Ensino Médio: um atalho para o passado. Educação \& Sociedade: revista de ciência da educação, Campinas, v. 38, nº 139, p. 373-384, abr./jun. 2017. Disponível em: http:// www.scielo.br/pdf/es/v38n139/1678-4626-es-38-139-00373.pdf. Acesso em: 21 nov. 2017.

DIÓGENES, E. M. N. A dinâmica histórica das políticas públicas no Brasil. In: ANDRADE, F. A.; SANTOS, J. M. C. T. (org.). Ditos e interditos em educação brasileira. Curitiba: CRV, 2012. p. 13-23.

FRIGOTTO, G. Educação e Trabalho: Bases para debater a educação profissional emancipadora. Perspectiva, Florianópolis, v. 19, n.1, p. 71-87, jan./jun., 2001. Disponível em: https://periodicos. ufsc.br/index.php/perspectiva/article/view/8463. Acesso em: 9 dez. 2013.

GRAMSCI, A. Cadernos do Cárcere. v. 2. 3. ed. Edição e tradução: Carlos Nelson Coutinho; coedição, Luiz Sérgio Henrique e Marco Aurélio Nogueira. Rio de Janeiro: Civilização Brasileira, 2004 .

GUIA DO ESTUDANTE. Entenda as ocupações nas escolas. São Paulo: Guia do Estudante, 09 nov. 2016. Disponível em: https:/guiadoestudante.abril.com.br/blog/atualidades-vestibular/ entenda-as-ocupacoes-nas-escolas/. Acesso em: 11 abr. 2021.

KUENZER, A. (Org.). Ensino Médio: construindo uma proposta para os que vivem do trabalho. São Paulo: Cortez, 2000.

KUENZER, A.; GRABOWSK, G. A produção do conhecimento no campo da educação profissional no regime de acumulação flexível. Holos, [S.l.], v. 6, p. 22-32, out. 2016. Disponível em: http:// www2.ifrn.edu.br/ojs/index.php/HOLOS/article/view/4983. Acesso em: 15 abr. 2021.

KUENZER, A. Reforma da educação profissional ou ajuste ao regime de acumulação flexível?. Revista Trabalho, Educação e Saúde, Rio de Janeiro, v. 5, n. 3, p. 491-508, nov. 2007. Disponível em: https://www.scielo.br/scielo.php?pid=S1981-77462007000300009\&script=sci_ abstract\&tlng=pt. Acesso em 15 abr.2021.

MARX, K.; ENGELS, F. Textos sobre educação e ensino. São Paulo: Moraes, 1992. 
NASCIMENTO, M. N. M. Ensino Médio no Brasil: determinações históricas. Publicatio UEPG - Ciências humanas, linguística, letras e artes, Ponta Grossa, v. 15, n. 1, p. 77-87, jun. 2007. Disponível em: https://revistas2.uepg.br/index.php/humanas/article/view/594. Acesso em: 19 abr. 2021.

NEVES, L.M.W. Ensino médio, ensino técnico e educação profissional: delimitando campos. In: NEVES. M. L. W (Org.). Educação e política no limiar do século XXI. Campinas: SP. Autores Associados, 2008.

OLIVEIRA, R.A (des)qualificação da educação profissional brasileira. São Paulo: Cortez, 2003.

ORLANDI, E. P. Análise de discurso: princípios e procedimentos. 12. ed. Campinas, SP: Pontes Editores, 2015.

ORLANDI, E. P. As formas do silêncio: no movimento dos sentidos. 6. ed. Campinas, SP: Editora da Unicamp, 2007b.

ORLANDI, E. P. Interpretação: autoria, leitura e efeitos do trabalho simbólico. 5. ed. Campinas: Pontes, 2007a.

ORSO, P. J. A Educação em tempos de golpe, ou então, como avançar andando para trás. Germinal: marxismo e educação em debate, Salvador, v. 9, n. 1, p. 50-71, abr., 2017. Disponível em: https://periodicos.ufba.br/index.php/revistagerminal/article/view/21735. Acesso em: 15 abr. 2021.

PÊCHEUX, M. Análise do discurso: três épocas (1983). Tradução: Jonas de A. Romualdo. In: GADET, F.; HAK, T. Por uma análise automática do discurso: uma introdução à obra de Michel Pêcheux. 5. ed. Campinas, SP: Editora da Unicamp, 2014a. p. 307-315.

PÊCHEUX, M. Semântica e discurso: uma crítica à afirmação do óbvio. Tradução: Eni Puccinelli Orlandi et al. 5. ed. Campinas: Editora da Unicamp, $2014 \mathrm{~b}$.

PONCE, A. Educação e luta de classes. 18. ed. Tradução: José Severo de Camargo Pereira. São Paulo: Cortez, 2001.

REDE BRASIL ATUAL. MP 746, contestada por especialistas e estudantes, é aprovada pela Câmara. São Paulo: Rede Brasil Atual, 8 dez. 2016. Disponível em: https://www.redebrasilatual. com.br/educacao/2016/12/contestada-por-especialistas-e-estudantes-camara-aprovamp-746-6627/. Acesso em: 11 abr. 2021.

Recebido para publicação em: 20 abr. 2021. Aceito para publicação em: 28 set. 2021. 